\title{
Evaluation of a Small Scale UV-treated Recirculating Depuration System for Oysters (Crassostrea iredalei)
}

\author{
Jerson C. Sorio ${ }^{1, *}$, Jose P. Peralta ${ }^{2, *}$ \\ ${ }^{1}$ College of Fisheries and Marine Sciences, Samar State University Mercedes Campus, Catbalogan, Samar, Philippines \\ ${ }^{2}$ Institute of Fish Processing Technology, University of the Philippines Visayas, Miagao, Iloilo, Philippines \\ *Corresponding author: jearzonesorio@gmail.com; f153@yahoo.com
}

\begin{abstract}
Oysters are filter-feeding organisms that tend to concentrate any suspended materials in its surrounding water including pathogenic bacteria. Since most oysters are eaten as raw or slightly cooked, they can act as vectors for pathogenic microorganisms and thus impose health risks to consumers. Depuration is one of the methods to reduce pathogenic bacteria in oysters to make it safe for sale and consumption. This study was designed to evaluate the effectiveness of the small scale UV- treated recirculating depuration system manipulating different parameters such as water flow rate and tank density. It aims to determine the effect of this UV-treated recirculating depuration system in reducing pathogenic bacteria in oysters such as E. coli, Salmonella, Vibrio cholera and Vibrio parahaemolyticus, and with the survival rate and meat yield of oysters. The experimental results showed that the depuration system was effective in reducing $E$. coli at different water flow rate $(15 \mathrm{~L} / \mathrm{min}, 10 \mathrm{~L} / \mathrm{min}$ and $5 \mathrm{~L} / \mathrm{min})$, in all density level (2 oysters/L, 4 oysters/L and 6 oysters/L). However, for Vibrio parahaemolyticus and Vibrio cholera reduction, only water flow rate of $15 \mathrm{~L} / \mathrm{min}$ at density level of 2 oysters $/ \mathrm{L}$ and 4 oysters $/ \mathrm{L}$ revealed to be effective. The survival of the oysters was high in treatments with a density of 2 oysters/ $\mathrm{L}$. The meat yield revealed to have no significant difference $(P<0.01)$ between treatments with water flow rates. In general, treatment with water flow rate of $15 \mathrm{~L} / \mathrm{min}$ in combination with 2 oysters/L density showed most promise results on all analysis.
\end{abstract}

Keywords: oyster, recirculating, depuration system, E.coli, Vibrio, flow rate, density

Cite This Article: Jerson C. Sorio, and Jose P. Peralta, "Evaluation of a Small Scale UV-treated Recirculating Depuration System for Oysters (Crassostrea iredalei)." American Journal of Food Science and Technology, vol. 5, no. 4 (2017): 117-124. doi: 10.12691/ajfst-5-4-1.

\section{Introduction}

Oysters (Crassostrea iredalei) are soft-bodied bivalve mollusk, usually found in the marine or estuarine environment [1]. They can grow in all tropical seas and are considered to be a valuable food item. They constitute a rich source of essential macro and micronutrients in providing a balanced diet [1]. The edible oysters are very popular food in the South East Asian countries, Europe, Australia, and USA [1]. Oysters are usually consumed raw. This leads to the potential risks and transmission of pathogenic microorganisms from contaminated areas [2].

The consumption of contaminated bivalve shellfish is associated with a number of human diseases, particularly when oysters are ingested as raw [3].Since oysters are filter feeders, they tend to absorb and concentrate pathogenic microorganisms; particularly when the shellfish originated from contaminated areas [2].Seafood is the main source of animal protein by more than a billion people globally, and contaminated seafood is a frequent etiology of diseases contracted from the ocean, including both pathogenic and chemical contamination [4]. Coliform bacteria and Escherichia coli are common indicators of microbiological infection of shellfish and monitoring shellfish contamination. However, monitoring shellfish bacterial contamination does not always detect viral contamination [5]. Health problems due to contaminated bivalve shellfish have been described and viral contamination has been linked to numerous cases of gastroenteritis, as well as outbreaks of various illnesses [4].

The microbiological quality of bivalves is closely related to the aquatic habitat that varies with factors such as environmental conditions and bacterial load of the water [6]. Contamination of mollusks with human pathogenic bacteria is linked to wastewater, and which are naturally present in coastal environments [7]. Contamination of bivalve shellfish occurs mainly because they are suspension feeders that selectively filter small particles of phytoplankton, zooplankton, viruses, bacteria and inorganic matter from the surrounding water $[8,9]$. The Food and Drug Administration [10] have required the shellfish industry to use fecal coliforms as indicators of contamination in harvesting waters and oysters. If the $E$. coli is detected above the most probable number (MPN) of 230/100 $\mathrm{g}$ of oyster, then the shellfish is subject for purification. Further, European Union (EU) regulations for mollusks, in addition to the absence of Vibrio sp. and Salmonella sp., a maximum tolerable cell concentration is required both for fecal coliforms (300 MPN/100 g meat) and Escherichia coli (230 MPN/100g meat) [11]. One strategy developed for the management of this risk is the depuration of the bivalves.

The risk of illness associated with the consumption of bivalves can be reduced by growing or farming of shellfish in 
areas with low levels of microbial contaminants. The risk may be further reduced by treating the shellfish such as depuration [12]. Depuration is a commercial practice where the harvested shellfish are placed in tanks filled with clean seawater for several hours to allow the shellfish to filter and their purge contaminants $[2,13]$. This method reduces the levels of microorganisms present in mollusc tissue, thus decreasing the potential for infections that are associated with shellfish ingestion. Depuration of shellfish is usually employed to reduce the bacterial load present and likewise decrease the potential for infections associated with shellfish consumption. There are two types of depuration system being used: flow through and recirculating. Flow through system uses natural seawater to continuously flow on the tanks, making it susceptible to fluctuations in the microbial community composition [1]. Recirculating system requires artificial seawater to be constantly cycled through after sterilization [15].

The use of ultraviolet (UV) for disinfecting water is commonly used in a depuration system. Depuration using UV light is usually effective provided that the water flow rate is adequate to its capacity [15]. UV disinfection technology can be readily applied, is low maintenance, results in significant viability reductions of all waterborne pathogens, and produces no hazardous by-products $[16,17]$. UV radiation eliminates enteric bacteria, viruses, bacterial and protozoan spores in the water without the production of toxic by-products or other chemical residues [13]. Also, depuration effectively inactivates Salmonella typhimurium from oysters when UV radiation and chlorine

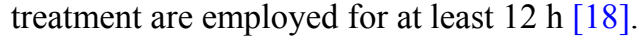

The technology of oyster depuration has been well studied in different countries of temperate regions $[1,19,20]$, and is reviewed by Oliveira et al. [21]. However, there is very limited scientific information regarding oyster depuration in the tropical regions using a small scale UV-treated recirculating depuration system. In the Philippines, there are no reports on depuration using recirculating system in combination with UV as disinfection for the purification of oysters [1].

The aim of this study was to evaluate the effectiveness of the small-scale UV-treated recirculating depuration system to reduce bacterial load in oysters by manipulating water flow rate and oyster density.

\section{Materials and Methods}

Approximately 80 kilos of oyster (Crassostrea iredalei) samples measuring 50-60 mm shell length, 40-30 mm shell width, 5-10 mm shell thickness, and weighing 40-50g were collected in the coastal part of Dumangas, Iloilo, Philippines $\left(10^{\circ} 47^{\prime} 52.8^{\prime \prime} \mathrm{N} 122^{\circ} 40^{\prime} 25.9^{\prime \prime} \mathrm{E}\right)$. The selection of the sampling site was based on the data of oyster production of Region VI in the Philippines, where the area was identified as one of the major producers [22]. Ease of transportation was also considered. The production in the area was sufficient enough to provide samples for the experiment.

\subsection{Collection of Oyster Samples}

Oysters were transported from the site to the UPV laboratory in Miagao, Iloilo, Philippines, within 2 hours. They were carried in a perforated styrophore box, covered with damp cloth to keep them moist. Oysters were cleaned immediately after arrival by gently brushing to remove mud, sand, barnacles and other unwanted particles. Samples were carefully inspected; dead or damaged specimens were eliminated. Only live and healthy oysters were subjected for the depuration process. The depuration system was disinfected by UV for $12 \mathrm{~h}$ prior to the placement of oysters in tanks and depuration process.

\subsection{Recirculating Depuration System}

The depuration tank is a closed system that re-circulates seawater. The depuration system consisted of nine $66 \times 43 \times 28 \mathrm{~cm}(50 \mathrm{~L})$ depuration tanks with perforated plastic trays ( 2 trays per tank) for the placement of oysters (Figure 1). The water from the storage water tank $(155 \mathrm{~L})$ is recirculated by a submersible pump ( $1 / 2$ horse power) at an adjusted rate of $5400 \mathrm{~L} / \mathrm{h}$. The sterilizing system consisted of one 55 Watts UV (24 gallon/min.) unit and a water filter with $10 \mu \mathrm{m}$ filter cartridge. The water flow rate in every tank was adjusted using a control valve. The depuration tank has a water level control outlet which enables the water to flow out of the tank without overflowing. From the outflow, water goes back to the storage water tank passing through a cloth filter to remove dirt from the depuration tanks.

\subsection{Depuration Experiment}

Oysters were placed in the plastic trays, raised at least $25 \mathrm{~mm}$ off the bottom of the tank to restrict recontamination with feces and accumulated dirt. Artificial seawater was used in the experiment in order to control the salinity of the water. The salinity and temperature in the depuration tanks were remained constant. The salinity of the water was maintained at $25 \mathrm{ppt}$ (parts per thousand) and temperature was at ambient state i.e. $28-30{ }^{\circ} \mathrm{C}$. The water flow rate was adjusted to 5,10 and $15 \mathrm{~L} / \mathrm{min}$. while the oyster density was 2 oysters/L, 4 oysters/L and 6 oysters/L. Tank with static (no water flow) artificial seawater was maintained as the control. Water parameters such salinity, temperature and dissolved oxygen was monitored at 0,24 , and $48 \mathrm{~h}$. The depuration assays were performed for a total of $48 \mathrm{~h}$.

\subsection{Experimental Design}

The Experimental design employed in this experiment is $3 \mathrm{x} 4$ factorial with four levels of treatments of water flow rate and three levels of oyster density. Treatment combination in the experiment is executed three times on every level of water flow rate (F) and oyster density (D), as shown in Table 1.

Table 1. Factorial combination of treatments of water flow rate and oyster density

\begin{tabular}{|c|c|c|c|c|c|}
\hline \multicolumn{2}{|c|}{ Factors } & \multicolumn{4}{|c|}{ Flow rate $(\mathrm{F})$} \\
\hline & & $\mathrm{F} 1$ & $\mathrm{~F} 2$ & F3 & $\mathrm{F} 4$ \\
\hline & & Static & $5 \mathrm{~L} / \mathrm{min}$ & $10 \mathrm{~L} / \mathrm{min}$ & $15 \mathrm{~L} / \mathrm{min}$ \\
\hline \multirow{3}{*}{$\begin{array}{c}\text { Density } \\
\text { (D) }\end{array}$} & $\begin{array}{c}\mathrm{D} 1 \\
\text { 2oysters/L }\end{array}$ & F1D1 & F2D1 & F3D1 & F4D1 \\
\hline & $\begin{array}{c}\mathrm{D} 2 \\
\text { 4oysters/L }\end{array}$ & F1D2 & F2D2 & F3D2 & F4D2 \\
\hline & $\begin{array}{c}\mathrm{D} 3 \\
\text { 6oysters/L }\end{array}$ & F1D3 & F2D3 & F3D3 & F4D3 \\
\hline
\end{tabular}



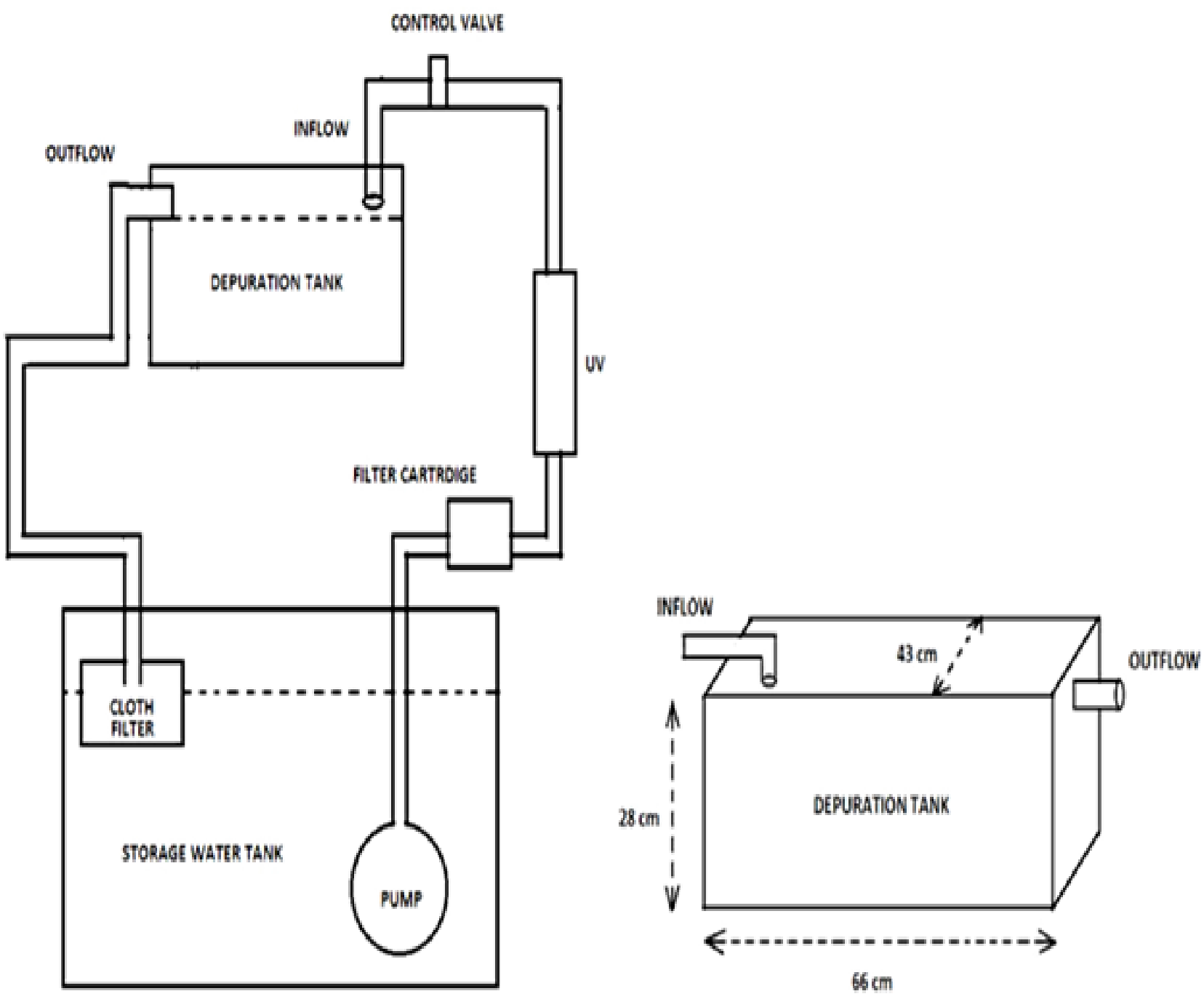

Figure 1. Diagram o the small-scale recirculating depuration system for oysters

\subsection{Enumeration of $E$. coli (MPN Method)}

E. coli was determined using the conventional five-tube, 3-dilution MPN method [40]. One hundred grams oyster meat sample was homogenized in $100 \mathrm{ml}$ of $0.1 \%$ phosphate buffer. Dilution tubes (up to $10^{3}$ ) were prepared and $2 \mathrm{ml}$ of each dilution was inoculated into each tube of lactose broth. Each tube contained inverted Durham tubes. Tubes were incubated at $35^{\circ} \mathrm{C}$ for $24-48 \mathrm{hrs}$. All tubes that showed turbidity and gas production were inoculated to $E$. coli broth and incubated at $44.5^{\circ} \mathrm{C}$ in water bath for 24 hrs.

A loopful of sample from positive $E$. coli broth was inoculated in tryptone and incubated for $24 \mathrm{~h}$ at $35^{\circ} \mathrm{C}$. $E$. coli was confirmed positive through indole production in tryptone by adding Kovac's reagent [24,25]. Quantification was determined using the MPN table and $E$. coli was reported as MPN $/ 100 \mathrm{~g}$ sample. Analysis was done before and after the depuration process.

\subsection{Vibrio parahaemolyticus (MPN Method)}

Vibrio parahaemolyticus was determined using MPN method. A 25-gram homogenized sample was mixed in $225 \mathrm{ml} \mathrm{0.1 \%}$ alkaline peptone water (APW) supplemented with $3 \% \mathrm{NaCl}$. Decimal dilutions were prepared $\left(\mathrm{A}, 10^{2}, 10^{3}\right)$ and $1 \mathrm{ml}$ of each dilution was transferred to three tubes containing $10 \mathrm{ml} 0.1 \%$ APW with $3 \% \mathrm{NaCl}$. They were incubated at $35^{\circ} \mathrm{C}$ for $24 \mathrm{hrs}$. After incubation, they were streaked on thiosulfate-citrate bile salts-sucrose agar (TCBS) plates and were incubated for 24 hours at $35^{\circ} \mathrm{C}$. Blue-green colonies were determined as Vibrio parahaemolyticus and were subjected to biochemical screening [23]. Quantification was determined using the MPN table and was reported as MPN/g sample.

\subsection{Vibrio cholerae Detection}

Twenty five grams of homogenized sample was mixed in $225 \mathrm{ml}$ of $0.1 \%$ alkaline peptone water (APW) added with $3 \% \mathrm{NaCl}$. Serial dilution was performed $\left(10^{2}, 10^{3}\right)$ in $9 \mathrm{ml}$ APW tubes. They were incubated for $6-8 \mathrm{~h}$ and $16-24$ hat $37^{\circ} \mathrm{C}$ and $42^{\circ} \mathrm{C}$. A loopful from each tube was streaked into two plates of pre-poured thiosulfate-citrate bile saltssucrose agar (TCBS) and was incubated for $24 \mathrm{~h}$. Yellow typical colonies were determined as Vibrio cholera and were subjected to biochemical screening [23].

\subsection{Survival and Meat Yield of Oysters}

Live oysters were counted after the depuration experiment to calculate the percentage survival rate. The meat yield was determined by shucking the oysters and weighing the meat using an electronic weighing balance. 
Percentage meat yield was calculated using the formula below [26,27]:

MY (\%) :[ wet meat weight $(\mathrm{g}) /$ total weight $(\mathrm{g})] \mathrm{X} 100$.

\subsection{Physico-chemical Parameters}

Water parameters such as salinity, temperature and dissolved oxygen (DO) were monitored at 0,24 and $48 \mathrm{~h}$ using refractometer, thermometer and DO meter, respectively. Monitoring of water parameters should be undertaken during depuration, at the beginning, in the middle and at the end [1].

\subsection{Statistical Analysis}

Statistics were performed using SPSS Version 20 (SPSS Inc., USA). A univariate ANOVA was used to determine the effects of water flow rate and oyster density on the bacterial count. A Duncan post-hoc test was run to determine which factors were significant. All tests were set at a significance level of $\mathrm{p}<0.01$.

\section{Results and Discussion}

\subsection{Physicochemical Parameters of the Recirculation Water in the Depuration System}

The physicochemical parameters of the recirculated artificial seawater in the depuration system are shown in Table 2. The salinity and temperature of the water in the sampling site were determined to be $25 \mathrm{ppt}$ and $30^{\circ} \mathrm{C}$ respectively. The salinity of the water in the depuration system was kept at $25 \mathrm{ppt}$ and the temperature varies from $28-30^{\circ} \mathrm{C}$. Reports have demonstrated that the optimal temperature and salinity of depuration process water are related to the ambient environmental conditions at the harvest site [28]. In this study, the temperature and salinity of the water in the sampling site and in the depuration system were almost similar. The Food and Agriculture Organization [1] had recommended a salinity of $25 \mathrm{ppt}$ for oysters (species not identified) in a depuration process. In the Philippines, a minimum salinity of $17.5 \mathrm{ppt}$ for Crassostrea iredalei during depuration process is specified [29]. For dissolved oxygen requirement, above $5 \mathrm{mg} / \mathrm{L}$ is recommended in a depuration system [1].

\subsection{Initial Count of Bacteria in Oysters}

The initial count of bacteria in oysters was determined prior to every depuration experiment (Table 3 ). Based on the data, the initial count of bacteria in oysters were beyond the standard microbiological limit. It was observed that in the third run, higher levels of E. coli and Vibrio parahaemolyticus were recorded compared to the previous runs. This might be due to the different sampling time in every run. Run 1 and 2 were conducted on the month of March, while run 3 was conducted on the month of April. Several studies proved that the microbial load of oysters varies over time [30], which is influenced by weather, distribution, and rate of pollution in the harvesting area $[7,31,32]$.

\subsection{Reduction of $E$. coli Count in Oysters}

The mean MPN count and percentage reduction of $E$. coli in oysters after the depuration process are shown in Table 4. Based on the results, all treatments with water flow rates $(\mathrm{L} / \mathrm{min})$ of 5,10 and $15(\mathrm{~F} 2, \mathrm{~F} 3, \mathrm{~F} 4)$ in all density levels have reduced $E$. coli count in oysters to an acceptable microbiological limit of 230 MPN /100g. Treatment with water flow rate of $15 \mathrm{~L} / \mathrm{min}$ in combination with 2 oysters/L density (F4D1) has the lowest count of $12 \mathrm{MPN} / 100 \mathrm{~g}$. Treatments with no water flow rate or static (F1) in all density levels retained high count after the depuration process.

Treatments with water flow rate of $15 \mathrm{~L} / \mathrm{min}$ in combination with 2 oysters/ L density (F4D1) has the highest $E$. coli reduction of $96.3 \%$. But has no significant difference $(p<0.01)$ to treatments with lower water flow rate of $10 \mathrm{~L} / \mathrm{min}$ at different oyster densities (F3D1, F3D2 and F3D3). Treatments with no water flow rate or static (F1) in all density levels have the lowest reduction ranging from 12.3 to $25.9 \%$ only. This result suggests that $E$. coli can be reduced in any water flow rates and oyster density levels. Using static method of depuration is not effective in reducing high levels of $E$. coli in oysters.

Table 2. Physicochemical parameters of recirculated water in the depuration tanks in all treatments

\begin{tabular}{cccc}
\hline Treatment & $\begin{array}{c}\text { Salinity } \\
(\mathrm{ppt})\end{array}$ & $\begin{array}{c}\text { Temperature } \\
\left({ }^{\circ} \mathrm{C}\right)\end{array}$ & $\begin{array}{c}\text { Dissolved oxygen } \\
(\mathrm{mg} / \mathrm{L})\end{array}$ \\
\hline F1D1 & 25 & 28 & 5.0 \\
F1D2 & 25 & 28 & 4.5 \\
F1D3 & 25 & 28 & 4.4 \\
F2D1 & 25 & 30 & 6.0 \\
F2D2 & 25 & 30 & 5.6 \\
F2D3 & 25 & 30 & 5.5 \\
F3D1 & 25 & 30 & 6.3 \\
F3D2 & 25 & 30 & 5.6 \\
F3D3 & 25 & 30 & 5.5 \\
F4D1 & 25 & 30 & 6.3 \\
F4D2 & 25 & 30 & 5.7 \\
F4D3 & 25 & 30 & 5.5 \\
\hline
\end{tabular}

Table 3. Initial count of pathogenic indicators in oysters prior to depuration process.

\begin{tabular}{|c|c|c|c|c|}
\hline \multirow{2}{*}{ Pathogenic bacteria } & \multicolumn{3}{|c|}{ Initial count } & \multirow{2}{*}{ Standard limit (USFDA, etc.) } \\
\hline & R1 & R2 & R3 & \\
\hline E. coli & 280 & 220 & 350 & $<230 \mathrm{MPN} / 100 \mathrm{~g}$ \\
\hline Vibrio cholera & Positive & Positive & Positive & Negative \\
\hline Salmonella & Negative & Negative & Negative & Negative \\
\hline
\end{tabular}

Legend: (R1) = First run: March 6, 2017, (R2) = Second run: March 20, 2017, (R3) = Third run: April 3, 2017. 
Table 4. Mean MPN count and percentage reduction of $E$. coli in oysters after depuration process in all treatments

\begin{tabular}{|c|c|c|c|c|c|}
\hline \multirow{2}{*}{ Treatment } & \multicolumn{4}{|c|}{ E. coli count MPN/100g } & \multirow{2}{*}{$\%$ reduction $($ Mean $\pm \mathrm{SD})$} \\
\hline & R1 & $\mathbf{R 2}$ & $\mathbf{R 3}$ & Mean & \\
\hline F1D1 & 220 & 140 & 280 & 213 & $25.9 \pm 9.1^{\mathrm{a}}$ \\
\hline F1D2 & 240 & 170 & 280 & 230 & $19.0 \pm 4.3^{a b}$ \\
\hline F1D3 & 280 & 170 & 350 & 267 & $12.3 \pm 11.5^{b}$ \\
\hline F2D1 & 23 & 17 & 90 & 43 & $87.1 \pm 8.6^{\mathrm{cd}}$ \\
\hline $\mathrm{F} 2 \mathrm{D} 2$ & 30 & 21 & 80 & 44 & $84.7 \pm 9.0^{\mathrm{cd}}$ \\
\hline F2D3 & 40 & 27 & 90 & 52 & $82.6 \pm 7.2^{c}$ \\
\hline F3D1 & 17 & 4 & 50 & 24 & $92.9 \pm 6.5^{\mathrm{de}}$ \\
\hline F3D2 & 21 & 7 & 70 & 33 & $90.4 \pm 9.2^{\mathrm{cde}}$ \\
\hline F3D3 & 14 & 6 & 70 & 30 & $89.8 \pm 8.7^{\mathrm{cde}}$ \\
\hline F4D1 & 7 & 2 & 27 & 12 & $96.3 \pm 3.6^{\mathrm{e}}$ \\
\hline F4D2 & 9 & 2 & 30 & 14 & $95.8 \pm 3.9^{\mathrm{e}}$ \\
\hline F4D3 & 9 & 2 & 40 & 17 & $94.8 \pm 5.5^{\mathrm{e}}$ \\
\hline
\end{tabular}

The results of this study proved the effectiveness of the small scale UV-treated recirculating depuration system in reducing E. coli in oysters Crassostrea iredalei. Similar results were reported where $79 \%$ reduction of $E$. coli was observed using a UV-treated recirculating depuration setup for $24 \mathrm{~h}$ with a water flow rate of $5.5 \mathrm{~L} / \mathrm{m}$ and oyster density of 2 oysters/L [33]. In this study, treatments with water flow rate of $5 \mathrm{~L} / \mathrm{min}$ in combination with 2 oysters/L density (F2D1) reduced E. coli by $87.1 \%$. Likewise, reduction of naturally occurring $E$. coli counts in the Japanese oyster $C$. gigas, to less than the detection limit (30 E. coli MPN/100 g) after depuration with UV-treated seawater for $24 \mathrm{~h}$ at a rate of $10 \mathrm{~L} / \mathrm{min}$ were reported [34]. In this study, treatments with flow rate of $10 \mathrm{~L} / \mathrm{min}(\mathrm{F} 3)$ have reduced $E$ coli count to $24-33 \mathrm{MPN} / 100 \mathrm{~g}$.

Furthermore, significant reductions of $E$. coli counts reaching undetected levels using UV treated recirculating depuration set-up for 48 hours with a flow rate of 2.9 $\mathrm{L} / \mathrm{min}$ and a density of 2 oysters/L were also reported [35]. Also, reduction of $E$. coli to less than $230 \mathrm{MPN} / 100 \mathrm{~g}$ for $48 \mathrm{~h}$ using UV treated seawater at a density of 2 oysters/L was studied [36]. Also, reduction of E. coli to less than $230 \mathrm{MPN} / 100 \mathrm{~g}$ for $48 \mathrm{~h}$ using UV treated seawater at a density of 2 oysters/L was studied [36].

In this study, treatments with flow rate of $10 \mathrm{~L} / \mathrm{min}(\mathrm{F} 3)$ have reduced $E$ coli count to $24-33 \mathrm{MPN} / 100 \mathrm{~g}$.

Furthermore, significant reductions of $E$. coli counts reaching undetected levels using UV treated recirculating depuration set-up for 48 hours with a flow rate of 2.9 $\mathrm{L} / \mathrm{min}$ and a density of 2 oysters/L were also reported [35]. Also, reduction of $E$. coli to less than $230 \mathrm{MPN} / 100 \mathrm{~g}$ for $48 \mathrm{~h}$ using UV treated seawater at a density of 2 oysters/L was studied [36].

\subsection{Reduction of Vibrio in Oysters}

Table 5 shows the mean MPN count and percentage reduction of Vibrio parahaemolyticus in oysters after the depuration process. Results indicated that only treatments with water flow rate of $15 \mathrm{~L} / \mathrm{min}$ in combination with densities of 2 oysters/L and 4 oysters/L (F4D1 and F4D2) have reduced $V$. parahaemolyticus in oysters below the microbiological standard limit of $100 \mathrm{MPN} / \mathrm{g}$. In terms of percentage reduction, treatment with water flow rate of 15 $\mathrm{L} / \mathrm{min}$ in combination with 2 oysters/L density (F4D1) has the highest reduction of $73.6 \%$. But shows no significant difference $(P<0.01)$ to F4D2 $(15 \mathrm{~L} / \mathrm{min}: 2$ oysters/L) and F3D1 (10 L/min: 2 oysters/L) treatments with a reduction of $66 \%$ and $52.9 \%$, respectively.

Detection of Vibrio cholera in oysters after depuration process is shown in Table 6. Based on the data, only treatments with water flow rate of $15 \mathrm{~L} / \mathrm{min}$ in combination with 2 oysters/L and 4 oysters/L densities (F4D1 and F4D2) had eliminated the bacteria in oysters. Other treatments including the static (control) retained its presence after the 48 hours depuration process.

The results of this study concur with other investigations which reported the persistence of Vibrio species in shellfish after depuration in UV-treated recirculating system. Depuration is a very effective process for the elimination of faecal bacteria, such as E. coli, but is less effective for naturally occurring Vibrio species [2].Low temperature depuration is recommended by several reports to reduce Vibrio in shellfishes [2,37,38]. Several studies reported that depuration process at ambient temperatures of above $20^{\circ} \mathrm{C}$ is not effective for eliminating Vibrio spp. in shellfish $[39,40,41]$. The ineffectiveness of depuration at ambient temperatures for reducing levels of Vibrio in oysters might be due to multiplication of Vibrio cells in oyster tissues when the water temperature increased to $26^{\circ} \mathrm{C}$ or higher [14]. The optimal growth temperature for $V$. parahaemolyticus is between 30 and $35^{\circ} \mathrm{C}$ with an upper growth limit of $45.3^{\circ} \mathrm{C}$ [14]. In this study, the temperature of the water in the depuration system was at ambient state $\left(28-30^{\circ} \mathrm{C}\right)$ during the entire experiment. Persistence of the bacteria may be due to the ambient temperature of the water in the depuration system.

Significant change in levels of $V$. parahaemolyticus in oysters Crassostrea gigas depurated in UV-treated artificial seawater at ambient temperature $\left(25^{\circ} \mathrm{C}\right)$ for up to $24 \mathrm{~h}$ were reported [42]. However, depuration at low temperature of $15^{\circ} \mathrm{C}$ has been reported capable of reducing $V$. parahaemolyticus in the Crassostrea virginica by 2.1 and $2.9 \log \mathrm{MPN} / \mathrm{g}$, after 48 hours depuration in UV-treated depuration system [43]. Depuration with refrigerated seawater at $5^{\circ} \mathrm{C}$ reduced $V$. parahaemolyticus populations by $>3.0 \log \mathrm{MPN} / \mathrm{g}$ in the Pacific oysters Crassostrea gigas without significant fatality of the oysterswere demonstrated [38]. Furthermore, a reduction of $10 \mathrm{MPN} / \mathrm{g}$ in the count of $V$. parahaemolyticus and Vibrio cholerae in oysters after $44 \mathrm{~h}$ of depuration at 16 to $18^{\circ} \mathrm{C}$ was reported [2]. 
Table 5. Mean MPN count and percentage reduction of Vibrioparahaemolyticus in oysters after depuration process in all treatments

\begin{tabular}{cccccc}
\hline Treatment & \multicolumn{3}{c}{ Vibrio parahaemolyticus MPN/g } & \% reduction \\
\cline { 2 - 4 } & R1 & $\mathbf{R 2}$ & $\mathbf{R 3}$ & Mean & (Mean \pm SD) \\
\hline F1D1 & 210 & 150 & 210 & 190 & $25.9 \pm 12.6^{\mathrm{abc}}$ \\
F1D2 & 210 & 150 & 290 & 217 & $22.4 \pm 13.3^{\mathrm{ab}}$ \\
F1D3 & 240 & 210 & 240 & 230 & $9.9 \pm 8.9^{\mathrm{a}}$ \\
F2D1 & 150 & 93 & 150 & 131 & $49.0 \pm 11.9^{\mathrm{cde}}$ \\
F2D2 & 160 & 120 & 150 & 143 & $43.9 \pm 9.2^{\mathrm{bcde}}$ \\
F2D3 & 210 & 160 & 240 & 203 & $21.0 \pm 10.9^{\mathrm{ab}}$ \\
F3D1 & 120 & 120 & 150 & 120 & $52.9 \pm 4.9^{\mathrm{def}}$ \\
F3D2 & 120 & 120 & 120 & 130 & $49.4 \pm 0.9^{\mathrm{cde}}$ \\
F3D3 & 150 & 210 & 160 & 173 & $31.6 \pm 16.9^{\mathrm{abcd}}$ \\
F4D1 & 64 & 64 & 75 & 68 & $73.6 \pm 0.5^{\mathrm{f}}$ \\
F4D2 & 93 & 75 & 93 & 87 & $66.0 \pm 4.1^{\mathrm{ef}}$ \\
F4D3 & 160 & 150 & 210 & 173 & $32.8 \pm 4.9^{\mathrm{abcd}}$ \\
\hline
\end{tabular}

* Non-identical superscript letters indicate a significant difference at $\mathrm{P}<$ 0.01 .

Table 6. Vibrio cholerae in oysters after depuration process in all treatments

\begin{tabular}{ccccc}
\hline & \multicolumn{4}{c}{ Vibrio cholera } \\
\cline { 2 - 5 } TREATMENT & R1 & R2 & R3 & Mean \\
\hline F1D1 & + & + & + & + \\
F1D2 & + & + & + & + \\
F1D3 & + & + & + & + \\
F2D1 & + & + & - & + \\
F2D2 & + & + & - & + \\
F2D3 & + & + & + & + \\
F3D1 & + & - & + & + \\
F3D2 & + & - & + & + \\
F3D3 & + & + & + & + \\
F4D1 & - & - & - & - \\
F4D2 & - & - & + & - \\
F4D3 & + & - & + & + \\
\hline
\end{tabular}

Legend: $(+)=$ positive, $(-)=$ negative, $(\mathrm{R} 1)=$ first run, $(\mathrm{R} 2)=$ second run, (R3) $=$ third run

\subsection{Survival Rate of Oysters after Depuration Process}

Table 7 shows the percentage survival of oysters after the 48 hours depuration process. Based on the results, treatments with water flow rate of $15 \mathrm{~L} / \mathrm{min}$ in combination with 2 oysters/L density (F4D1) has the highest survival rate of $85.1 \%$. But shows no significant difference $(P<0.01)$ to F2D1 $(5 \mathrm{~L} / \mathrm{min}: 2$ oysters/L) and F3D1 $(10 \mathrm{~L} / \mathrm{min}: 2$ oysters/L) treatments with a survival rate of $82.9 \%$. It was observed that all treatments having a high density of 6 oysters/L (D3) have low survival rate ranging from 50.41 to $53.3 \%$. It may be due to the low dissolved oxygen level in treatments with higher densities (Table 2) compared to treatments with lower densities.

\subsection{Meat yield of Oysters after the Depuration Process}

The meat yield of the oysters was determined after $48 \mathrm{~h}$ of depuration (Table 8). Based on the results, treatments with no water flow rate or static at different oyster densities (F1D1, F1D2 and F1D3) have the highest meat yield ranging from 18.7 to $18.9 \%$ with a percentage reduction of 0.75 to 4.9. Treatments with water flow rates (F2, F3 and F4) in all density levels have lower meat yield ranging from 14.5 to $16.4 \%$ only with a percentage reduction of 13.8 to 21.7 . The result suggests that the meat yield was influenced by the water flow rate. However, there are no reports regarding the effect of flow rate on the meat yield of oysters during depuration. The decrease of meat yield in oysters may be due to the purging of contaminants including bacteria and other organic matter into the water, and are being washed away from the tanks. While oysters in static condition purge contaminants into the water and remains in the tank throughout the depuration process. Thus, there is a possibility that the contaminants where again filtered and accumulated in the oysters.

Table 7. Average percentage survival of oysters after depuration process in all treatments

\begin{tabular}{cc}
\hline TREATMENT & $\begin{array}{c}\text { \% Survival rate } \\
(\text { Mean } \pm \text { SD) }\end{array}$ \\
\hline F1D1 & $75.9 \pm 2.0^{\mathrm{a}}$ \\
F1D2 & $61.5 \pm 1.2^{\mathrm{b}}$ \\
F1D3 & $52.4 \pm 2.3^{\mathrm{c}}$ \\
F2D1 & $82.9 \pm 1.3^{\mathrm{d}}$ \\
F2D2 & $71.9 \pm 2.1^{\mathrm{a}}$ \\
F2D3 & $52.0 \pm 5.5^{\mathrm{c}}$ \\
F3D1 & $82.9 \pm 3.5^{\mathrm{d}}$ \\
F3D2 & $71.9 \pm 2.1^{\mathrm{a}}$ \\
F3D3 & $51.7 \pm 1.5^{\mathrm{c}}$ \\
F4D1 & $85.1 \pm 2.0^{\mathrm{d}}$ \\
F4D2 & $73.4 \pm 2.7^{\mathrm{a}}$ \\
F4D3 & $53.3 \pm 1.0^{\mathrm{c}}$ \\
\hline
\end{tabular}

* Non-identical superscript letters indicate a significant difference at $\mathrm{P}<$ 0.01 .

Table 8. Meat yield reduction of oysters after depuration process in all treatments

\begin{tabular}{cc}
\hline TREATMENT & $\begin{array}{c}\text { \% reduction } \\
\text { (Mean } \pm \text { SD) }\end{array}$ \\
\hline F1D1 & $0.75 \pm 0.4^{\mathrm{a}}$ \\
F1D2 & $1.5 \pm 1.6^{\mathrm{a}}$ \\
F1D3 & $4.9 \pm 6.7^{\mathrm{a}}$ \\
F2D1 & $16.2 \pm 1.9^{\mathrm{bc}}$ \\
F2D2 & $19.7 \pm 2.6^{\mathrm{bc}}$ \\
F2D3 & $13.8 \pm 1.9^{\mathrm{b}}$ \\
F3D1 & $20.1 \pm 2.1^{\mathrm{bc}}$ \\
F3D2 & $21.7 \pm 4.9^{\mathrm{c}}$ \\
F3D3 & $16.8 \pm 4.3^{\mathrm{bc}}$ \\
F4D1 & $20.9 \pm 4.5^{\mathrm{bc}}$ \\
F4D2 & $19.4 \pm 5.0^{\mathrm{bc}}$ \\
F4D3 & $21.7 \pm 4.8^{\mathrm{bc}}$
\end{tabular}

* Non-identical superscript letters indicate a significant difference at P $<$ 0.01 . 


\subsection{Effectiveness of the Recirculating Depuration System}

Depuration of shellfishes requires additional production costs which could be the reason why some shellfish producers do not invest into this [44]. However, it is suggested that depuration promotes the development of economic activities aiming towards better utilization of bivalve molluscs [45]. They further argued that improving the microbial quality of oysters increases the commercial value of the product. Depuration is one the most effective method of reducing bacteria in shellfishes requiring less time of purification than relaying which took at least 2 months [21]. The effectiveness of depuration process depends on the design of the set-up, species [46], physiological condition [44], initial concentration of bacteria [21], water temperature and salinity in the tanks [20]. Every unique design of depuration set-up requires appropriate purification condition such as flow rate and density that is suitable for the design.

This research study has developed a small scale UV-treated recirculating depuration system that effectively reduces pathogenic bacteria in oysters (Crassostrea iredalei). Furthermore, the result of this study could serve as baseline information for future studies that will assay other factors such as temperature and salinity in order to establish optimal purification condition to completely eliminate pathogenic bacteria in oysters.

\section{Conclusion}

This study preliminary proved the effectiveness of the small scale depuration system design for the reduction of pathogenic bacteria to improve the microbial quality of oysters as well as increasing its market value. Furthermore, the result of this study could serve as baseline information for future studies that will assay other factors such as temperature and salinity in order to establish optimal purification condition to completely eliminate pathogenic bacteria in oysters.

\section{Acknowledgements}

This research was funded by the Department of Science and Technology - Accelerated Science and Technology Human Resource Development Program (DOST-ASTHRDP).

\section{References}

[1] Food and Agriculture Organization of the United Nations. (2008) Fisheries Technical Paper.Available on: http://www.fao.org/icatalog/search/result.asp?subcat_id=36 accessed at October 28, 2009.

[2] Croci, L., Suffredini, E., Cozzi, L., Toti, L., 2002. Effects of depuration of molluses experimentally contaminated with Escherichia coli, Vibrio cholerae $\mathrm{O} 1$ and Vibrio parahaemolyticus. Journal of Applied Microbiology 92, 460-465.

[3] Myrmel EMM, Berg E, Rimstad A, Grinde B 2004. Detection of en $\neg$ teric viruses in shellfish from the Norwegian coast. Appl Environ Microbiol 70: 2678-2684.

[4] Fleming LE, Broad K, Clement A, Dewailly E, Elmir S, Knap A, Pomponi SA, Smith S, Gabriele H, Walsh P 2006. Oceans and human health: emerging public health risks in the marine environment. Mar Pollut Bull 53: 545-560.

[5] Formiga-Cruz M, Allard AK, Conden-Hansson AC, Henshilwood K, Hernroth BE, Jofre J, Lees DN, Lucena F 2003. Evaluation of potential indicators of viral contamination in shellfish and their applicability to diverse geographical areas. Appl Environ Micro $\neg$ biol 69: 1556-1563.

[6] Martinez-Urtaza, J., Simental, L., Velasco, D., DePaola, A., Ishibashi, M., Nakaguchi, Y., Nishibuchi, M., Carrera-Flores, D., Rey-Alvarez, C., Pousa, A. 2005. Pandemic Vibrio parahaemolyticus O3:K6, Europe. Emerging Infectious Disease, 11, 1319-1320.

[7] Rippey SR. 1994. Infectious diseases associated with molluscan shellfi sh consumption. Clin Microbiol Rev. 7:419-425.

[8] Burkhardt, W. III, Calci, K.R. 2000. Selective accumulation may account for shellfish associated viral illness. Applied and Environmental Microbiology, 66(4), 1375-1378.

[9] Dunphy B. J., Hall J.A., Jeffs A.G. Wells R.M.G. 2006. Selective Particle feeding by the Chilean oyster, Ostrea chilensis; implications for nursery culture and broodstock conditioning. Aquaculture, vol. 261pg.59.

[10] Food and Drug Administration. 2009. National Shellfish Sanitation Program Guide for the Control of Molluscan Shellfish 2009 Revision.

[11] Maffei M., Vernocchi P., Lanciotti R., Guerzoni M.E., Belletti N., Gardini F. (2009): Depuration of striped venus clam (Chamelea gallina L.): Effects on microorganisms, sand content, and mortality. Journal of Food Science, 74, 1-7.

[12] Richerds GP, Mcleod C., Le Guyader SF. 2010. Processing strategies to inactivate enteric viruses in shellfish. Food Environ Virol 2:183-193.

[13] Rodrick, G.E., Schneider, K.R., 2003. Molluscan shellfish depuration. In: Proceedings of the Fourth International Conference on Molluscan Shellfish Safety, Santiago de Compostela, Spain, June 4-8, Consellerı'a de Pesca y Asuntos Maritimos de Xunta de Galicia and Intergovernamental Oceanographic Commision of UNESCO, pp. 210-218

[14] Sakazaki R. 1983. Vibrio parahaemolyticus as a food-spoilage organism. In: Rose AH, editor. Food Microbiology. New York: Academic Press. p 225-241.

[15] Lewis M, Rikard S, Arias C. R. 2010. Evaluation of a FlowThrough Depuration System to Eliminate the Human Pathogen Vibrio Vulnificus from Oysters. J Aquac Res Development 1:103.

[16] Hijnen W., Beerendonk E., and Medema G. 2006. Inactivation credit of UV radiation for viruses, bacteria and protozoan (oo) cysts in water: A review.

[17] Morita S., Namikoshi A., Hirata T., Oguma K., Katayama H., Ohgaki S., Motoyama N., and Fujiwara M. 2002. Efficacy of UV irradiation in inactivating Cryptosporidium parvum oocysts. Appl. Environ. Microbiol. Nov;68(11):5387-93.

[18] Correa A.A. Albarnaz J.D. Moresco V. Poli CR, Teixeira AL, Simoes CMO, Barardi CRM. 2007. Depuration dynamics of oysters (Crassostrea gigas) aritificially contaminated by Salmonella enterica serovar Typhimurium. Mar. Environ. Res 63: 479-489.

[19] Kelly, C. B. 1961. Disinfection of seawater by UV radiation. Am. J. Public Health 51:1670-1680.

[20] Love, D. C., G. L. Lovelace \& M. D. Sobsey. 2010. Removal of Escherichia coli, Enterococcus fecalis, coliphages MS2, poliovirus and hepatitis A virus from oysters (Crassostrea virginica) and hardshell clam (Mercinaria mercinaria) by depuration. Int. J. Food Microbiol. 143:211-217.

[21] Oliveira, J., A. Cunha, F. Castilho, J. L. Romalde \&M. J. Pereira. 2011. Microbial contaminants and purification of bivalve shellfish: crucial aspects in monitoring and future perspectives: a minireview. Food Contr. 22:805-816.

[22] Philippines Statistics Authority (PSA). 2015. Fisheries Situationer, January-December 2015. https://psa.gov.ph/content/fisheriessituationer-january-december-2015.>(accessed on May 31, 2017).

[23] US Foods and Drugs Administration. 1998. Bacteriological Analytical Manual. Virginia: Association of Offical Analytical Chemists, 1998.

[24] American Public Health Association (APHA). Compendium of methods for the microbiological examination of foods. C. V anderzant and D.F. Splittstoesser eds. Washington D.C. 1992.

[25] Lalitha K. V. and P. K. Surendran, 2004. Bacteria micro-flora associated with farmed freshwater prawn Macrobrachium 
rosenbergii (De Man) and the aquaculture environment. Aquaculture Research, 35: 629-635.

[26] Freeman, K.R., 1974. Growth, mortality and seasonal cycle of Mytilus edulis in two Nova Scotian embayments. Bedford Inst. of Oceanography Publ., Dartmouth, Canada.

[27] Yildiz Harun, Selcuk Berber, Sefa Acarli \& Pervin Vural. 2011. Seasonal variation in the condition index, meat yield and biochemical composition of the flat oyster Ostrea edulis (Linnaeus, 1758) from the Dardanelles, Turkey, Italian Journal of Animal Science, 10:1, e5.

[28] Shumway, S.E, Rodrick. G.E. 2009. Shellfish safety and quality. Woodhead Publishing Limited and CRC Press LLC. FL, Cambridge, UK, 608 pp.

[29] Palpal-Latoc E.Q., Caoile S.J.S. and Cariaga A.M. 1986. Bacterial depuration of oyster (Crassostrea iredalei Faustino) in the Philppines, p 293-295. In: Maclean JL, Dizon LB and Hosillos (eds). The First Asian Fisheries Forum. Asian Fisheries Society, Manila, Philippines.

[30] Hayat SM, Javed B, Razzaq S. 2007. Growth performance of metal stressed major carps viz. catla catla, Labeo rohita and Cirrhina mrigala reared under semi-intensive culture system. Pakistan Vet J27: 812.

[31] Lipp EK, Kurz R, Vincent R, Rodriguez-Palacios C, Farrah SR, Rose JB. 2001. The effects of seasonal variability and weather on microbial fecal pollution and enteric pathogens in a subtropical estuary. Estuaries Coast 24:266-76.

[32] Lynch M, Painter J, Woodruff R, Braden C. 2006. Centers for Disease Control and Prevention Surveillance for foodbornedisease outbreaks -United State, 1998 - 2002. MMWR Surveill Summ 55: 1-42.

[33] Corrales- Vega Luis A., Carolina Marín Vindas, Oscar Pacheco Prieto \& Gerardo Zúñiga Calero. (2013). Preliminary assessmen of small scale bacterial depuration of Crassostreagigas and Anadara spp., Gulf of Nicoya, Costa Rica. Rev. Mar.Cost. ISSN 1659-455X. Vol. 5: 107-117.

[34] Kasai, H., K. Kawana, M. Labaiden, K. Namba \&M. Yoshimu. 2011. Elimination of Escherichia coli from oysters using electrolysed seawater. Aquaculture 319:315 318.

[35] Anacleto Patrícia , Ana Luísa Maulvault, Milena Chaguri, Sónia Pedro, Maria Leonor Nunes, Rui Rosa, António Marques. (2013) Microbiological responses to depuration and transport of native and exotic clams at optimal and stressful temperatures. Food Microbiology.
[36] Chinnadurai Shunmugavel, Kolliyil Sunil Mohamed, Vellathi Venkatesan, Jenni Sharma and Vasanth Kripa. (2014). Depuration of Bacterial Populations in the Indian Backwater Oyster Crassostrea madrasensis (Preston, 1916): Effects on Surface andBottom Held Oysters. Journal of Shellfish Research, 33(2): 409-414.

[37] Phuvasate, S., Chen, M.H., Su, Y.C. 2012 Reductions of Vibrio parahaemolyticus in Pacific Oysters (Crassostrea gigas) by Depuration at Various Temperatures, Food Microbiology.

[38] Su, Y.-C., Yang, Q., \& Häse, C. (2010). Refrigerated seawater depuration for reducing Vibrio parahaemolyticus contamination in pacific oyster (Crassostrea gigas). Journal of Food Protection, 73, 1111-1115.

[39] Son, N.T., Fleet, G.H., 1980. Behavior of pathogenic bacteria in the oyster, Crassostrea commercialis during depuration, re-laying and storage. Applied and Environmental Microbiology 40, 994-1002.

[40] Eyles, M. J., and G. R. Davey. 1984. Microbiology of commercial depuration of the Sydney rock oyster, Crassostrea commercialis. J. Food Prot. 47:703-706. Environmental Toxicology, 19, 143-153.

[41] Timoney, J. F., \& Abston, A. 1984. Accumulation and elimination of Escherichia coli and Salmonella typhimurium by hard clams in an in vitro system. Applied and Environmental Microbiology, 47, 986-988.

[42] Ren, T., \& Su, Y.-C. 2006. Effects of electrolyzed oxidixing water treatment on reducing Vibrio parahaemolyticus and Vibrio vulnificus in raw oysters. Journal of Food Protection, 69, 1829-1834.

[43] Chae, M. J., D. Cheney \& Y. C. Su. 2009. Temperature effects on the depuration of Vibrio parahaemolyticus from the American oyster (Crassostrea virginica). J. Food Sci. 74:62-66.

[44] Cusson, M., Tremblay, R., Daigle, G. \& Roussy, M. (2005). Modeling the depuration potential of blue mussels (Mytilus spp.) in response to thermal shock. Aquaculture, 250, 183-193.

[45] de Abreu, A., Albarnaz, J. D., Moresco, V., Poli, C. R., Teixeira, A. L., Oliveira, C. M. \& Monte, C. R. 2007. Depuration dynamics of oysters (Crassostrea gigas) artificially contaminated by Salmonella enterica serovar Typhimurium. Mar. Environ. Res., 63(5), 479-489.

[46] Lees, D., Younger, A., Dore, B. 2010. Depuration and relaying. In: Rees, G., Pond, K., Kay, D., Bartram, J., Santo Domingo, J.S. (Eds.), Safe management of shellfish and harvest waters. World Health Organization (WHO), IWA Publishing, London, UK pp. 145-181. 